\title{
Introduction to Special Edition: The EU Faring Through its Post-Lisbon Crisis-Past, Present, Future of European Integration
}

\author{
Bleddyn Davies
}

Published online: 4 December 2013

(C) Springer Science+Business Media Dordrecht 2013

In 1973 the United Kingdom joined the then European Economic Community. Forty years on, UK remains a member of the European Union, but that Membership is no less controversial than it was on day one, and in many ways is more so. ${ }^{1}$ The only truly defining feature of the European Political Project in that time is change, both in terms of the shape and size of the Union, and in terms of its Constitutional arrangements and its legal powers. ${ }^{2}$

We have moved in 60 years from the European Coal and Steel Community to an economic and Political Union, with the power to legislate in fields as diverse as family life, consumer protection and criminal law; with a role in shaping policy from Fisheries, to Foreign Affairs. It is increasingly drawn to the trappings of Statehood. The Constitutional Treaty, had it been successfully adopted, would have put on a legal footing a flag and an anthem. ${ }^{3}$ Already, a hard core of EU States spend a common currency and follow the fiscal policies laid down by a central bank. It was the primary conduit through which the States of continental Europe dealt with the global financial crisis. It is, apparently, on the verge of creating its own Public Prosecutor. ${ }^{4}$ The Iron Curtain which scarred the continent fell in 1990, leading to the reunification of Germany, and then the EU's great move eastwards in 2004, when the UK went from being one amongst fifteen, to one amongst 25 , and in then in 9 more years went to being one amongst 28. So the life of the EU as a polity, and

\footnotetext{
1 "This Eurosceptic Isle; the Rise and Rise of British Euroscepticism", BBC, 25/2/13 http://www.bbc.co. uk/news/uk-politics-21572250.

2 Dougan (2008).

3 Article I-8, Constitutional Treaty.

${ }^{4}$ Commission Proposal for a Council Regulation on the Establishment of a European Public Prosecutors Office. COM (2013) 534 Final.
}

B. Davies $(\bowtie)$

Law School, Liverpool John Moores University, Redmonds Building, Brownlow Hill, Liverpool, UK

e-mail: B.R.Davies@ljmu.ac.uk 
particularly it's life during the UK's membership, can be defined by rapid growth, both in terms of its membership, population and economy, and by change.

While welcomed in some quarters as a natural move towards interstate cooperation in a post-Westphalian age, ${ }^{5}$ in others the dizzying pace of this change is decried as an assault on national sovereignty, and a betrayal of the national citizen by a distant political elite, both at home and abroad. Love it or loathe it however, the EU is here, apparently to stay.

From a parochial point of view, this fortieth anniversary of British Membership of the Union seems a welcome opportunity to pause and take stock of its current position. The articles published in this special section of the Liverpool Law Review are drawn from a conference held at Liverpool John Moores University in June of 2013; "The EU Faring through its Post-Lisbon Crisis: Past, Present, Future of European Integration". The conference was a great success as can be demonstrated by the papers which follow. In themselves these are a microcosm of the change and growth discussed above.

Harriet Gray's contribution discusses the Common European Asylum System and explores the operation of concepts of fairness and solidarity in that field. Dr Julia Bradshaw considers the development of European Citizenship and the obligations on the EU to extend the benefits of that concept to third country nationals or stateless refugees. Gloria Okemuo discusses the successes and, more pertinently, failures of the Common European Defence policy through the case study of recent the crisis in Mali. My own contribution deals with the Court of Justice development of its case law on the effect of European law on domestic Criminal tribunals.

With Euro scepticism becoming an increasingly powerful force in British politics, and arguably, in European Politics more generally, the future for the EU may be uncertain. What is clear is that it is growing and changing at a startling pace. Dashwood's "Constitutional Order of States" ${ }^{6}$ has, it appears grander ambitions. In an era of uncertainty, one thing is clear. The days when European Lawyers worried more or less exclusively about the shape of butter packets, or the alcohol contents of spirits, are, as this section clearly demonstrates, long behind us.

I would like to take this opportunity to thank the Review for allowing us this space to publish our proceedings and to the staff of Liverpool John Moores University, without whom the conference would have been possible. I would also like, of course to thank the contributors for their papers. In particular I would like to thank those who have gone on to publish their work in this journal, I am confident the work speaks for itself.

\section{References}

Dashwood, A. 1998. States in the European Union. European Law Review 23(3): 201.

Dougan, M. 2008. The Treaty of Lisbon 2007: Winning minds, not hearts. CMLRev 45: 617.

\footnotetext{
5 Sharp Rise in Euroscepticism in Germany, France, Italy and Spain", The Times, 17/9/2013 http://www. thetimes.co.uk/tto/news/world/europe/article3871247.ece.

6 Dashwood (1998).
} 